\title{
DNA methylation profile dynamics of tissue-dependent and differentially methylated regions during mouse brain development
}

Keiji Hirabayashi, Kunio Shiota and Shintaro Yagi

\begin{abstract}
Background: Tissues and their component cells have unique DNA methylation profiles comprising DNA methylation patterns of tissue-dependent and differentially methylated regions (T-DMRs). Previous studies reported that DNA methylation plays crucial roles in cell differentiation and development. Here, we investigated the genome-wide DNA methylation profiles of mouse neural progenitors derived from different developmental stages using HpyCH4IV, a methylation-sensitive restriction enzyme that recognizes ACGT residues, which are uniformly distributed across the genome.

Results: Using a microarray-based genome-wide DNA methylation analysis system focusing on 8.5-kb regions around transcription start sites (TSSs), we analyzed the DNA methylation profiles of mouse neurospheres derived from telencephalons at embryonic days 11.5 (E11.5NSph) and 14.5 (E14.5NSph) and the adult brain (AdBr). We identified T-DMRs with different DNA methylation statuses between E11.5NSph and E14.5NSph at genes involved in neural development and/or associated with neurological disorders in humans, such as Dclk1, Nrcam, Nfia, and Ntng1. These T-DMRs were located not only within $2 \mathrm{~kb}$ but also distal (several kbs) from the TSSs, and those hypomethylated in E11.5NSph tended to be in CPG island (CGI-) associated genes. Most T-DMRs that were hypomethylated in neurospheres were also hypomethylated in the AdBr. Interestingly, among the T-DMRs hypomethylated in the progenitors, there were T-DMRs that were hypermethylated in the AdBr. Although certain genes, including Ntng1, had hypermethylated T-DMRs $5^{\prime}$ upstream, we identified hypomethylated T-DMRs in the $\mathrm{AdBr}, 3^{\prime}$ downstream from their TSSs. This observation could explain why Ntng1 was highly expressed in the AdBr despite upstream hypermethylation.
\end{abstract}

Conclusion: Mouse adult brain DNA methylation and gene expression profiles could be attributed to developmental dynamics of T-DMRs in neural-related genes.

Keywords: DNA methylation, Tissue-dependent and differentially methylated region, Neural progenitor cells

\section{Background}

The adult mouse brain consists of various kinds of cells that sequentially appear as neurons, astrocytes, and oligodendrocytes from late gestation through the neonatal period. Distinctive neural progenitor cells (NPCs) that exhibit different differentiation potentials to neurons and glial cells are generated during mid-to-late gestation [1-3]. This process is controlled by signaling pathways composed of transcription factors; dysfunction in genes

\footnotetext{
* Correspondence: asyagi@mail.ecc.u-tokyo.ac.jp

Laboratory of Cellular Biochemistry, Department of Animal Resource

Sciences/Neterinary Medical Sciences, The University of Tokyo, Yayoi 1-1-1, Bunkyo-ku, Tokyo 113-8657, Japan
}

encoding these factors is known to result in brain malformation [4-6].

Epigenetic systems underlie the network of tissue- and developmental stage-specific transcription factors and their targets [7]. Major players in epigenetic systems are DNA methylation and histone modifications, which occur on nucleosomes and affect chromosomal activity by changing nucleosome architecture. Tissue-dependent and differentially methylated regions (T-DMRs) are found throughout the genome and influence tissue-specific gene expression. T-DMRs have been found $3^{\prime}$ downstream of transcription start sites (TSSs) in addition to in $5^{\prime}$-upstream promoter regions. A distinct combination of DNA methylation

\section{Biomed Central}




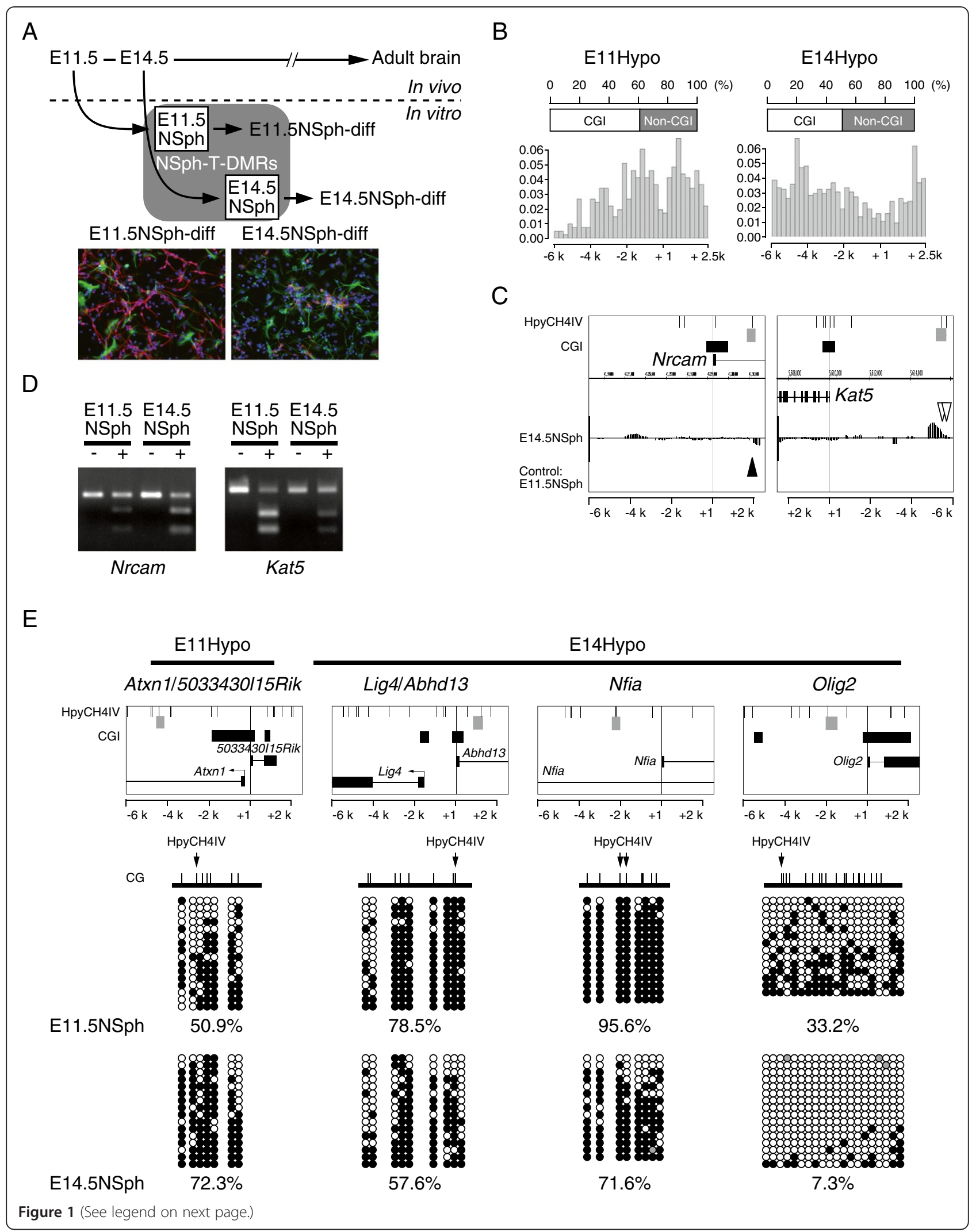




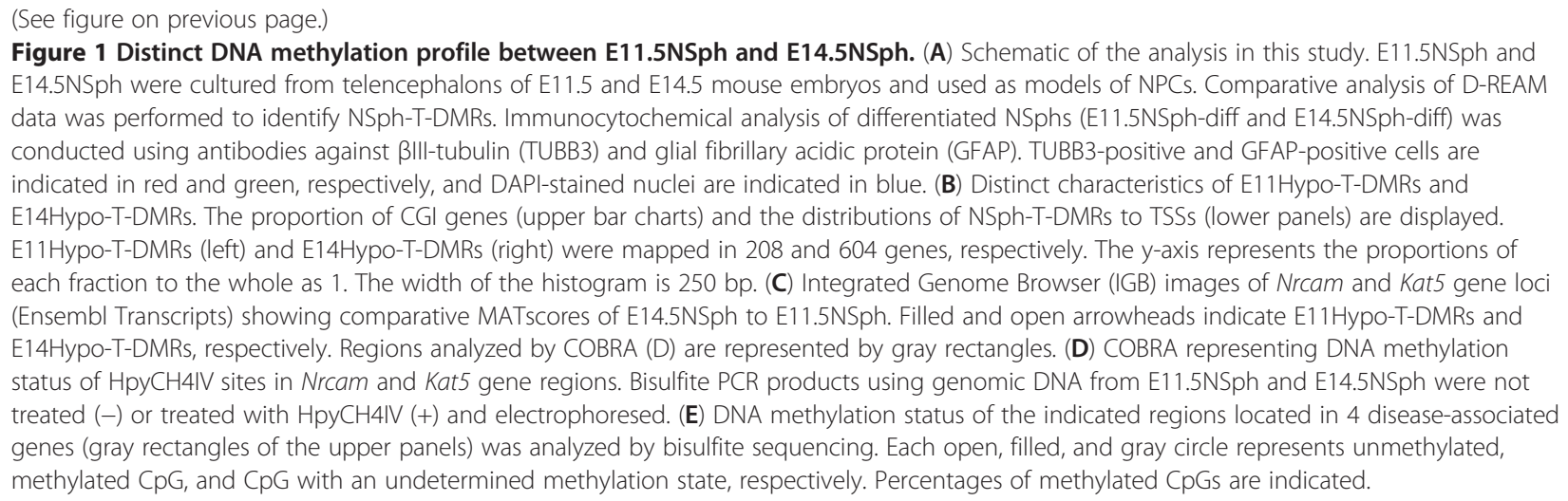

patterns at T-DMRs determines cellular identity during development [8-13], thus illustrating that DNA methylation profiles are unique to individual cells or tissue types $[7,14,15]$.

Genome-wide DNA methylation analyses focusing on proximal promoter regions in embryonic stem cell-derived NPCs and NPCs committed to astrocytes indicate the importance of DNA methylation in the commitment process and differentiation potential of NPCs [16-19]. These reports indicated that the majority of DNA methylation changes occur at low-CpG density promoters, suggesting sequence preferences in DNA methylation targets during neural differentiation [18]. However, T-DMRs are observed at high-CpG density promoters, such as those containing CpG islands (CGIs), and are tissue-dependently methylated in the adult brain (AdBr) $[7,20]$.

In this study, we performed a comparative analysis of DNA methylation status in NPCs derived from mid- and late-gestation mouse embryo. Using microarray-based, genome-wide DNA methylation profiling [7], we identified T-DMRs in dozens of genes, and we illustrate dynamic DNA methylation statuses for dozens of T-DMRs, which are reflected in the DNA methylation profile of the AdBr.

\section{Results}

\section{Distinct DNA methylation profiles in NPCs with different fates}

To explore DNA methylation profiles of mouse NPCs, we compared neurospheres (NSph) derived from telencephalons at embryonic days 11.5 (E11.5NSph) and 14.5 (E14.5NSph) by T-DMR profiling with restriction tag-mediated amplification (D-REAM) with mouse promoter tiling arrays covering from $6 \mathrm{~kb}$ upstream to $2.5 \mathrm{~kb}$ downstream of 30,140 gene TSSs (Ensembl Transcript IDs) [7]. The distinctive cell fates of E11.5NSph and E14.5NSph were indicated by biased expression of marker genes for neural and oligodendrocyte progenitor in the undifferentiated NSph, and those of neuronal and glial marker genes in the differentiated ones, respectively (Figure 1A and Additional file 1: Figure S1). We screened genomic regions that exhibited differential MATscores $[7,21]$ between NSphs, which indicate differential methylation status, and obtained a total of 1,403 NSph-T-DMRs consisting of 380 E11Hypo-T-DMRs and 1,023 E14HypoT-DMRs, which were hyper- and hypomethylated, respectively, in E14.5NSph compared to E11.5NSph.

The localization patterns along the genome were distinct between E11Hypo-T-DMRs and E14Hypo-T-DMRs. The former exhibited bimodal distributions within $2.5 \mathrm{~kb}$ from TSSs and biased to the CGI genes, which contain CGIs around TSSs [7]; the latter were located $6 \mathrm{~kb}$ to $2 \mathrm{~kb}$ upstream of TSSs without any promoter type bias (Figure 1B). These findings are noteworthy because they indicate that methylation changes occur in regions around high-CpG promoters. We analyzed E11Hypo-T-DMR 3' downstream from the Nrcam TSS, and E14Hypo-T-DMR $5^{\prime}$ upstream from the Kat5 TSS. Combined bisulfite restriction analysis (COBRA) of these T-DMRs indicated differential DNA methylation status as indicated by DREAM (Figure $1 \mathrm{C}$ and 1D).

Among the genes with NSph-T-DMRs, we identified human gene orthologs involved in neurological diseases, such as spinocerebellar ataxia type 1 (ATXN1 and KAT5), schizophrenia (BLOC1S1, NTNG1, and OLIG2), autism (NRCAM), and brain malformation syndrome (LIG4 and NFIA) (Additional file 2: Table S1). We performed bisulfite sequencing of 1 E11Hypo-T-DMR (Atxn1) and 3 E14HypoT-DMRs (Lig4, Nfia, and Olig2) that were located at various relative positions from the TSSs, including one associated with an alternative TSS and those facing their TSS in proximal regions. The results showed clear differences in the DNA methylation statuses of CpG sites around the HpyCH4IV sites between the 2 types of NSphs (Figure 1E). These data indicate that methylation changes occurred in a subpopulation of NSphs in a gene-dependent manner. 


\section{Association of NSph-T-DMRs with neural development and function}

We performed gene ontology (GO) analysis to characterize genes with the NSph-T-DMRs. The neural-related GO term "central nervous system development" was enriched in genes with E11Hypo-T-DMRs but was not enriched in those with E14Hypo-T-DMRs (Tables 1 and 2). Genes with E11Hypo-T-DMRs included those for neuronal differentiation and functions: specification of retinal amacrine neurons (Barhl2), axon outgrowth (Dclk1), inhibition of oligodendrocyte differentiation ( $I d 2)$, and axon guidance (B3gnt2 and Nrcam). Among genes with E14Hypo-TDMRs, we found those involved in astrocyte and/or oligodendrocyte development, such as Nfia and Olig2. Both E11Hypo- and E14Hypo-T-DMR genes included those involved in cell fate commitment (Barhl2, Olig2, and Cdon) and brain morphogenesis (Tcfap2a, Fezf1, Cer1, and Cdon). A search of the OMIM (Online Mendelian Inheritance in Man) database indicated that genes with E14Hypo-T-DMRs that encode membrane-associated proteins (Accn1, Scg5, and Slc15a2) are expressed in the AdBr (Table 2). Thus, developmental stage-specific methylation and demethylation at the T-DMRs in genes related to neuronal and glial development occurred during neural cell fate determination.

\section{DNA methylation profile of NSph-T-DMRs in the $\mathrm{AdBr}$}

We compared D-REAM data between NSphs and the $\mathrm{AdBr}$ and used K-means clustering to classify E11hypoand E14hypo-T-DMRs into 3 clusters. In the AdBr, most E11Hypo-T-DMRs and E14Hypo-T-DMRs exhibited hypomethylation (clusters 2 and 3) (Figure 2A). Although the degrees of differences varied among genes, COBRA of NSph-T-DMRs indicated hypomethylated status at some loci as clusters 2 and 3 (e.g., Dclk1 and B3gnt2 for E11Hypo-TDMR, and Rdh5/Bloc1s1 and $M c f 2 l$ for E14Hypo-T-DMRs), and hypermethylated status at other loci as cluster 1 (e.g., Cdkn2a and Ntng1 for E11Hypo- and E14Hypo-T-DMRs, respectively) in the

Table 1 Annotation analysis of genes with NSph-T-DMRs

\begin{tabular}{|c|c|c|}
\hline $\begin{array}{l}\text { Genes with } \\
\text { Category }\end{array}$ & $\begin{array}{l}\text { E11Hypo-T-DMRs } \\
\text { Term }\end{array}$ & $P$ value \\
\hline$\overline{\mathrm{BP}}$ & Central nervous system development & $1.01 \mathrm{E}-02$ \\
\hline MF & Cyclin-dependent protein kinase inhibitor activity & 1.57E-03 \\
\hline KEGG & Propanoate metabolism & $1.40 \mathrm{E}-03$ \\
\hline \multicolumn{3}{|c|}{ Genes with E14Hypo-T-DMRs } \\
\hline $\mathrm{BP}$ & Positive regulation of developmental process & $8.08 \mathrm{E}-03$ \\
\hline CC & Peroxisome & 7.43E-03 \\
\hline MF & Transmembrane transporter activity & $1.41 \mathrm{E}-02$ \\
\hline KEGG & Retinol metabolism & 2.80E-03 \\
\hline
\end{tabular}

BP, MF, KEGG, and CC indicate biological process, molecular function, KEGG pathway, and cellular component, respectively.
AdBr (Figure 2B and Additional files 3 and 4: Tables S2 and S3).

Among genes with cluster-1 E14Hypo-T-DMRs, we unexpectedly found that T-DMR hypermethylation was associated with higher gene expression in the brain (described later). To address this issue, we further investigated the DNA methylation status of other HpyCH4IV sites in these genes using AdBr D-REAM data and found AdBr-specific hypomethylated T-DMRs $3^{\prime}$ downstream of their TSSs in Ntng1, Aldh1a2, and Accn1 (Figure 3A). It is noteworthy that all these T-DMRs were located within few kb from CGIs.

The positional changes of hypomethylated T-DMRs in a specific genomic region are summarized in Figure 3B. Bisulfite sequencing analysis of T-DMRs in the Ntng1 gene indicated hypermethylation of E14Hypo-T-DMRs at the $5^{\prime}$-upstream region and hypomethylation at the $3^{\prime}$ downstream of the TSS in the AdBr with unmethylated neighboring regions in all samples (Figure 3C). Quantitative reverse-transcription polymerase chain reaction (Q-RT-PCR) data indicated negative correlation between hypomethylation at distal T-DMR (region 4) in undifferentiated NSphs, and an association of gene expression in AdBr with hypomethylation of the T-DMR 3 ' downstream of the CGI (Figure 3D). These results highlight functions associated with developmental stage-dependent multiple T-DMRs in a gene region.

\section{Discussion}

Comparing NSphs with different cell fates enabled the identification of numerous T-DMRs in genes at different relative positions from TSSs. DNA methylation and demethylation occurred in a developmental stagedependent manner, and changes in DNA methylation at these T-DMRs resulted in variable methylation in $\mathrm{AdBr}$ cells that shifted the DNA methylation profile as a whole. The hypomethylated status of most NSph-T-DMRs was reflected in the DNA methylation profile of the AdBr to different degrees in a locus-specific manner. The previous genome-wide methylation analyses of NPCs [16-18] emphasized preexisting epigenetic marks, such as bivalent histone modifications on poised genes involved in early differentiation processes and demethylated promoters of astrocyte-specific genes in progenitor cells preceding expression in differentiated cells. DNA methylation status in NSphs and gene expression in the $\mathrm{AdBr}$ have led to the hypothesis that a considerable number of T-DMRs identified in this study are epigenetically marked prior to gene expression. The developmental-stage specific DNA methylation marks could be useful for identify and evaluation of NPCs established from not only fetus but also stem cells as pluripotent stem cells and those from adult tissues. 
Table 2 Genes with NSph-T-DMRs annotated for neural development and functions

\begin{tabular}{|c|c|c|c|c|}
\hline NSph-T-DMR & Gene & Description & $\begin{array}{l}\text { GO terms related to development } \\
\text { and neural functions }\end{array}$ & OMIM \\
\hline E11Нypo & Atxn1 & Ataxin 1 & Transmission of nerve impulse & 601556 \\
\hline E11Нypo & B3gnt2 & $\begin{array}{l}\text { UDP-GlcNAc:betaGal beta-1, } \\
\text { 3-N-acetylglucosaminyltransferase } 2\end{array}$ & $A x, N D$, sensory perception & 605581 \\
\hline E11Нypo & Barhl2 & BarH-like 2 (Drosophila) & $A x, C C, N D$ & 605212 \\
\hline E11Нyро & Cdkn2a & Cyclin-dependent kinase inhibitor $2 \mathrm{~A}$ & & 600160 \\
\hline E11Нуро & Dclk1 & Doublecortin-like kinase 1 & $A x, N D$ & 604742 \\
\hline E11Нypo & $1 d 2$ & Inhibitor of DNA binding 2 & & 600386 \\
\hline E11Нyро & Nrcam & Neuron-glia-CAM-related cell adhesion molecule & $A x, N D$, transmission of nerve impulse & 601581 \\
\hline E11Нyро & Tcfap2a & Transcription factor AP-2, alpha & neural tube closure & 107580 \\
\hline E11Нypo/E14Нyро & Cer1 & Cerberus 1 homolog (Xenopus laevis) & & 603777 \\
\hline E14Нуро & Accnl & $\begin{array}{l}\text { Amiloride-sensitive cation channel } 1 \text {, } \\
\text { neuronal (degenerin) }\end{array}$ & Sensory perception & 601784 \\
\hline E14Нуро & Aldhia2 & $\begin{array}{l}\text { Aldehyde dehydrogenase family } 1 \text {, } \\
\text { subfamily A2 }\end{array}$ & ND & 603687 \\
\hline E14Нyро & Atp11a & ATPase, class VI, type $11 \mathrm{~A}$ & & 605868 \\
\hline E14Нуро & Bloc1s1 & $\begin{array}{l}\text { Biogenesis of lysosome-related organelles } \\
\text { complex-1, subunit } 1\end{array}$ & & 601444 \\
\hline E14Нypo & Cdon & $\begin{array}{l}\text { Cell adhesion molecule-related/down-regulated } \\
\text { by oncogenes }\end{array}$ & CC & 608707 \\
\hline E14Нyро & Dph5 & DPH5 homolog (S. cerevisiae) & & 611075 \\
\hline E14Нуро & Emid1 & EMI domain containing 1 & & 608926 \\
\hline E14Нуро & Fezfi & Fez family zinc finger 1 & $A x, N D$ & 613301 \\
\hline E14Нуро & Kat5 & K(lysine) acetyltransferase 5 & & 601409 \\
\hline E14Нуро & Lig4 & Ligase IV, DNA, ATP-dependent & Neuron apoptosis & 601837 \\
\hline E14Нуро & Mcf2l & Mcf.2 transforming sequence-like & & 609499 \\
\hline E14Нуро & Nfia & Nuclear factor I/A & & 600727 \\
\hline E14Нyро & Ntngl & Netrin G1 & $A x, N D$ & 608818 \\
\hline E14Нуро & Olig2 & Oligodendrocyte transcription factor 2 & $C C, N D$, gliogenesis, transmission of nerve impulse & 606386 \\
\hline E14Нyро & $\operatorname{Scg} 5$ & Secretogranin V & Neuropeptide signaling pathway & 173120 \\
\hline E14Нуро & Slc15a2 & $\begin{array}{l}\text { Solute carrier family } 15 \text { (H+/peptide transporter), } \\
\text { member } 2\end{array}$ & & 602339 \\
\hline E14Нуро & Wasl & Wiskott-Aldrich syndrome-like (human) & & 605056 \\
\hline
\end{tabular}

$\mathrm{Ax}$, axonogenesis; $\mathrm{CC}$, cell fate commitment; ND, neuron differentiation.

We observed developmental position changes such as $5^{\prime}$ distal hypomethylated T-DMRs in the NSphs and hypomethylated T-DMR marks $3^{\prime}$ proximal downstream of TSSs in the fully developed brain. These T-DMRs were often located around CGIs, which is in contrast to a previous genome-wide analysis of NPCs indicating biased DNA methylation changes to low-CpG promoters $[17,18]$. T-DMRs found in the Ntng1 locus could be classified into the previously described class of T-DMRs downstream of TSSs of CGI genes, in which hypomethylation was well correlated with gene expression $[7,20]$. T-DMRs have been identified at the edges of CGIs [22], and DMRs around CGIs, named as CpG island shores, are identified in not only normal tissues but also cancer cells [23]. The biased distribution of E14Hypo-T-DMRs to the relatively $5^{\prime}$-distal positions from TSSs suggested that hypomethylation of these $5^{\prime}$-distal T-DMRs in the progenitor cells are epigenetic marks that lead to expression in differentiated cells, which exhibit hypomethylation of T-DMRs at $3^{\prime}$ downstream of TSS.

Systematic biases are inevitable for any genome-wide DNA methylation analysis: both Microarray-based Integrated Analysis of Methylation by Isoschizomers (MIAMI) [16] and Reduced Representation Bisulfite Sequencing (RRBS) [18], methods used in the previous epigenomic study in NPCs, are inevitably focusing on CGIs because of the biased distribution of MspI recognition sites that they uses for enrichment of fragments [24]; Methylated DNA 


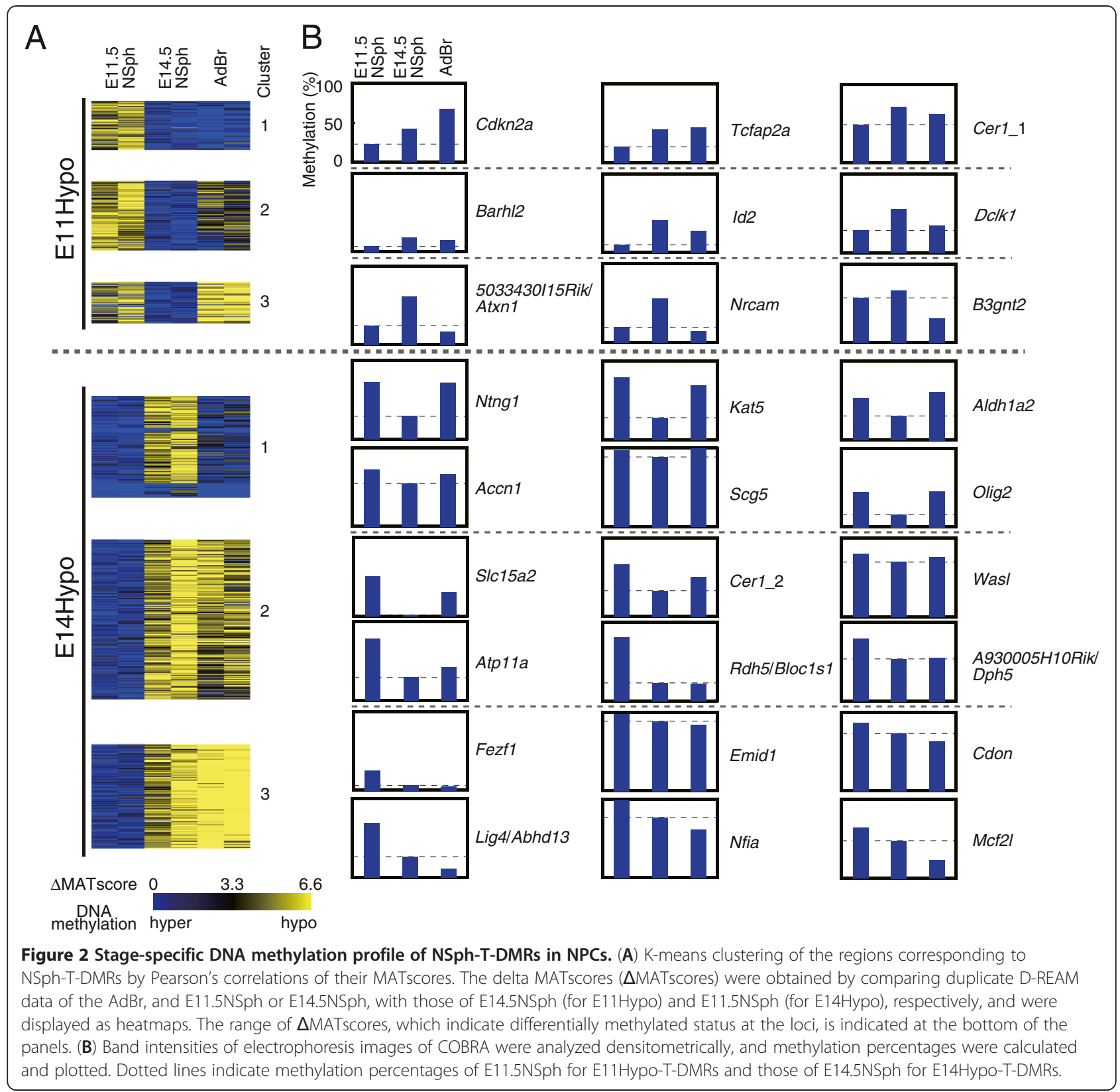

immunoprecipitation (MeDIP) [17], is known to have bias to high density CpG promoter [25]. Approximately 50\% of promoters are associated with CGIs. D-REAM also has $[7,25]$. Only limited numbers of genes are coincided to be predicted to have DMRs in NSph: Gfap, which have been shown to have DMR hypomethylated in E14.5NSph [18], was not included in our gene list because of lacking HpyCH4IV site in the proximal promoter region: DMRs on Ntng1, which was identified in this study, is an example of novel T-DMRs not described in the previous studies.

Several converging lines of evidence have indicated the significance of DNA methylation in normal brain function. Mutations in Dnmt1, Dnmt3b, and Mecp2 result in functional and/or morphological abnormalities in human and mouse brain [26-28]. Mutations in the human orthologs of some genes carrying NSph-T-DMR, such as LIG4 and NFIA, are associated with neurological disorders $[29,30]$. Similar phenotypes are observed in mice harboring mutations in these genes [4,31]. Targeted mutation of 2 genes with E11Hypo-T-DMRs, Dclk1 and Nrcam, results in axonal defects in mice [32,33]. Disorganized DNA methylation profiles have been reported in cloned animals [34], chemically treated cells [35], and in certain diseases [36,37]. Epimutations in tumor suppressor genes are involved in carcinogenesis [38]. Therefore, the establishment of DNA methylation status at T- 


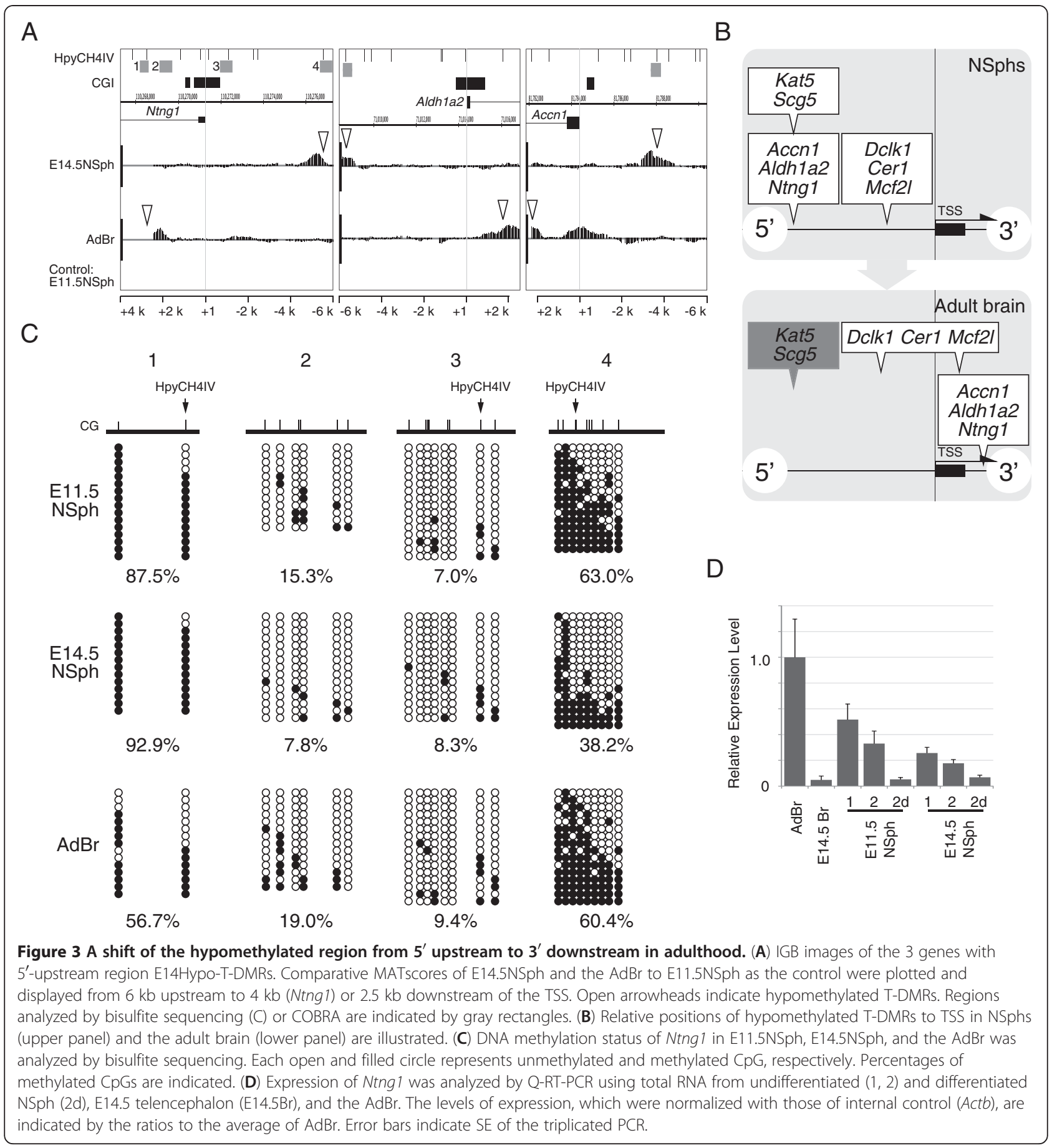

DMRs in these genes indicates the possibility that epimutations at T-DMRs could be involved in neurological disorders without genetic alterations.

\section{Conclusions}

The dynamics of T-DMRs, several of which are often identified around TSS of a single gene during neural development, contribute regulation of developmental expression of genes and the DNA methylation profile of mouse adult brain. The identified T-DMRs could be used for evaluation and identification of NPCs, and for epimutation analysis in neural diseases.

\section{Methods}

Tissue samples, neurosphere culture, and immunocytochemistry

All experiments using mice were carried out according to the institutional guidelines for the care and use of 
laboratory animals (Graduate School of Agricultural and Life Sciences, the University of Tokyo). Pregnant C57BL/ $6 \mathrm{~N}$ mice were euthanized, and fetuses were recovered in ice-cold phosphate-buffered saline (PBS) containing 0.6\% glucose. For neurosphere culture, dissected telencephalons were dispersed, and were suspended in progenitor cell culture medium: Dulbecco's modified Eagle's medium (DMEM)/F12 (1:1) containing $5.5 \mathrm{mM}$ HEPES, $2 \mathrm{mM} \mathrm{L-}$ glutamine, 1/50 volume of B-27 Supplement (Invitrogen), $20 \mathrm{ng} / \mathrm{ml}$ epidermal growth factor (EGF), $20 \mathrm{ng} / \mathrm{ml}$ human basic fibroblast growth factor (bFGF) (PeproTech), and $5 \mu \mathrm{g} / \mathrm{ml}$ heparin. Cells were seeded into a petri dish and cultured for 6 days, replacing half of the medium with fresh medium at day 3 . To induce differentiation, cells were dispersed, suspended in differentiation medium (progenitor cell culture medium without EGF, bFGF, and heparin), and seeded onto poly-L-lysine- and laminin-coated coverslips for immunocytochemistry. After 4 days of culture, cells were fixed with $4 \%$ paraformaldehyde and stained with a monoclonal antibody against $\beta$ III-tubulin (Covance) and a rabbit polyclonal antibody against glial fibrillary acidic protein (DAKO).

\section{Genomic DNA extraction}

Cells $\left(1.5 \times 10^{6}\right)$ were incubated in $200 \mu$ l of lysis solution (10 mM Tris- $\mathrm{HCl}$ (pH 8.0), $5 \mathrm{mM}$ EDTA, $200 \mathrm{mM}$ $\mathrm{NaCl}, 0.2 \%$ SDS and $200 \mu \mathrm{g} / \mathrm{ml}$ proteinase $\mathrm{K}$ ) at $55^{\circ} \mathrm{C}$ for $30 \mathrm{~min}$. The samples were extracted with phenol/chloroform/isoamyl alcohol (PCI; 25:24:1), incubated with RNase for $30 \mathrm{~min}$, and extracted again with PCI. Genomic DNA was precipitated with ethanol and dissolved in $20 \mu \mathrm{l}$ of TE (pH 8.0).

\section{D-REAM}

D-REAM was performed as previously described [7]. Genomic DNA $(5 \mu \mathrm{g})$ was digested with HpyCH4IV (New England Biolabs), extracted with PCI and chloroform, ethanol-precipitated, and dissolved in TE ( $\mathrm{pH}$ 8.0). DNA sample (50 ng) was ligated to the R-adaptor pair using T4 DNA ligase (New England Biolabs) at $16^{\circ} \mathrm{C}$ overnight. After the $5^{\prime}$-overhang of the adaptor was filled in with Klenow Fragment, the DNA was digested with TaqI at $65^{\circ} \mathrm{C}$ for at least $1 \mathrm{~h}$ and purified with a Microspin S-300 HR Column (GE Healthcare). The TaqI ends of the DNA were ligated to the $\mathrm{N}$-adaptor pair. The resulting DNA sample was purified with the Wizard SV Gel and PCR Clean-up System (Promega) and amplified with the R18 and N18 primers and Immolase Taq DNA polymerase (Bioline) under the following conditions: denaturation at $95^{\circ} \mathrm{C}$ for $7 \mathrm{~min}$, followed by 20 cycles of $30 \mathrm{sec}$ at $95^{\circ} \mathrm{C}, 30 \mathrm{sec}$ at $62^{\circ} \mathrm{C}$, and $2 \mathrm{~min}$ at $72^{\circ} \mathrm{C}$. DNA was purified with MinElute PCR Purification Kit (Qiagen), and $7.5 \mu \mathrm{g}$ of DNA was used for microarray analysis. Microarray analysis was conducted with GeneChip
System (Affymetrix), and all procedures were done according to the Affymetrix Chromatin Immunoprecipitation Assay Protocol. DNA samples were labeled with the GeneChip WT Double-Stranded DNA Terminal Labeling Kit and hybridized with GeneChip Mouse Promoter 1.0R Arrays. Arrays were stained and washed with GeneChip Fluidics Station 450 and scanned with GeneChip Scanner 30007 G. The instruments were operated with GeneChip Operating Software version 1.4. D-REAM data obtained in this study have been deposited in the ArrayExpress database (accession number E-MTAB-1150). The D-REAM dataset of the adult whole cerebrums (AdBr), which were obtained from 13 week-old male mice, is reported previously [7].

\section{Data analysis}

D-REAM data for two experiments were obtained for each NSph. The data were visualized using the Integrated Genome Browser (Affymetrix). Ensembl Transcript IDs (release 46) associated with T-DMR were obtained using BioMart [39] and Galaxy website [40]. Distribution analysis was conducted with the R software package. K-means clustering of MATscores was performed with the MultiExperiment Viewer ( $\mathrm{MeV}$ in TM4 Microarray Software Suite) [41]. Gene Ontology analysis was conducted using the DAVID Bioinformatics Resources website [42].

\section{Combined bisulfite restriction analysis (COBRA) and sequencing}

PstI- or EcoRV-digested genomic DNA $(3 \mu \mathrm{g})$ was denatured with $0.3 \mathrm{M} \mathrm{NaOH}$. Sodium metabisulfite ( $\mathrm{pH}$ 5.0) and hydroquinone were added to final concentrations of $2.0 \mathrm{M}$ and $0.5 \mathrm{mM}$, respectively. The reaction mixtures were incubated in the dark at $55^{\circ} \mathrm{C}$ for $16 \mathrm{~h}$. The DNA was purified with the Wizard DNA Clean-up System (Promega), treated with $0.3 \mathrm{M} \mathrm{NaOH}$ at $37^{\circ} \mathrm{C}$ for $15 \mathrm{~min}$, and ethanol-precipitated. The DNA was dissolved in $20 \mu \mathrm{l}$ of TE ( $\mathrm{pH}$ 8.0). After the bisulfite reaction, the unmethylated CpGs are converted to uracilphosphate-guanines (UpGs), whereas the methylated CpGs remain intact. One-hundredth to $1 / 20$ amount of the DNA was used for PCR with Immolase Taq DNA polymerase. For COBRA, one-tenth of the PCR product was digested with $\mathrm{HpyCH} 4 \mathrm{IV}$ at $37^{\circ} \mathrm{C}$ overnight and electrophoresed with untreated control in a $2 \%$ agarose gel. For sequencing, PCR product was purified with the Wizard SV Gel and PCR Clean-up System (Promega) and cloned into pGEM-T Easy Vector (Promega). Up to 16 clones were sequenced. Primer sets used are listed in Additional file 5: Table S2.

\section{RT-PCR}

Total RNA was extracted with the TRIzol Reagent (Invitrogen), and $1 \mu \mathrm{g}$ of total RNA was subjected to reverse 
transcription using the Superscript II First-strand Synthesis System (Invitrogen). One-hundredth of the cDNA was used for PCR with Immolase Taq DNA polymerase under the following conditions: denaturation at $95^{\circ} \mathrm{C}$ for $7 \mathrm{~min}$ and 23 or 35 cycles of $30 \mathrm{sec}$ at $95^{\circ} \mathrm{C}, 30 \mathrm{sec}$ at $62^{\circ} \mathrm{C}$, and $30 \mathrm{sec}$ at $72^{\circ} \mathrm{C}$ (Additional file 5: Table S2). Quantitative RT-PCR was carried-out on Bio-Mark HD system (Fluidigm) using Universal probes (Roche Applied Science) for monitoring amplifications (detailed in Additional file 6). Makers were selected according to the previous report [43].

\section{Additional files}

Additional file 1: Figure S1. NSph differentiation capacity.

Additional file 2: Table S1. Associations of genes carrying NSph-T-DMRs with human neurological disease.

Additional file 3: Figure S2. Integrated Genome Browser (IGB) images of the genes (Ensembl Transcripts) with E11Hypo- (A) and E14HypoT-DMRs (B).

Additional file 4: Figure S3. COBRA representing DNA methylation status of NSph-T-DMRs.

Additional file 5: Table S2. Primers used in this study.

Additional file 6: Method and Primer list for Q-RT-PCR.

\section{Abbreviations}

T-DMRs: Tissue-dependent and differentially methylated regions; TSSs: Transcription start sites; AdBr: Adult brain; CGls: CpG islands; NPCs: Neural progenitor cells; NSph: Neurospheres; D-REAM: T-DMR profiling with restriction tag-mediated amplification; COBRA: Combined bisulfite restriction analysis; GO: Gene ontology; Q-RT-PCR: Quantitative reversetranscription polymerase chain reaction.

\section{Competing interests}

The authors declare no conflicts of interest.

\section{Authors' contributions}

$\mathrm{KH}, \mathrm{KS}$ and SY designed this study. $\mathrm{KH}$ and SY performed the experiments, and analyzed data. KH, SY and KS prepared the manuscript. All authors read and approved the final manuscript.

\section{Acknowledgements \\ This work was supported by grants from the National Institute of Biomedical Innovation (NIBIO); Grant-in-Aid for Scientific Research (KAKENHI) from the Ministry of Education, Culture, Sports, Science, and Technology (MEXT), Japan; Core Research for Evolutional Science and Technology (CREST) of Japan Science and Technology Agency (JST) (SY). We acknowledge Dr. Koji Hayakawa, and Mr. Yasuyuki Tabei for their efforts to design primers for Q-RT-PCR.}

Received: 5 June 2012 Accepted: 31 January 2013 Published: 6 February 2013

\section{References}

1. Temple S: The development of neural stem cells. Nature 2001, 414:112-117.

2. Sauvageot CM, Stiles CD: Molecular mechanisms controlling cortical gliogenesis. Curr Opin Neurobiol 2002, 12:244-249.

3. Miller FD, Gauthier AS: Timing is everything: making neurons versus glia in the developing cortex. Neuron 2007, 54:357-369.

4. Mason S, Piper M, Gronostajski RM, Richards LJ: Nuclear factor one transcription factors in CNS development. Mol Neurobiol 2009, 39:10-23.
5. das Neves L, Duchala CS, Tolentino-Silva F, Haxhiu MA, Colmenares C, Macklin WB, Campbell CE, Butz KG, Gronostajski RM, Godinho F: Disruption of the murine nuclear factor I-A gene (Nfia) results in perinatal lethality, hydrocephalus, and agenesis of the corpus callosum. Proc Natl Acad Sci USA 1999, 96:11946-11951.

6. Zhang W, Yi MJ, Chen X, Cole F, Krauss RS, Kang JS: Cortical thinning and hydrocephalus in mice lacking the immunoglobulin superfamily member CDO. Mol Cell Biol 2006, 26:3764-3772.

7. Yagi S, Hirabayashi K, Sato S, Li W, Takahashi Y, Hirakawa T, Wu G, Hattori N, Hattori N, Ohgane J, Tanaka S, Liu XS, Shiota K: DNA methylation profile of tissue-dependent and differentially methylated regions (T-DMRs) in mouse promoter regions demonstrating tissue-specific gene expression. Genome Res 2008, 18:1969-1978.

8. Kremenskoy M, Kremenska Y, Ohgane J, Hattori N, Tanaka S, Hashizume K, Shiota K: Genome-wide analysis of DNA methylation status of CpG islands in embryoid bodies, teratomas, and fetuses. Biochem Biophys Res Commun 2003, 311:884-890.

9. Hattori N, Nishino K, Ko Y, Ohgane J, Tanaka S, Shiota K: Epigenetic control of mouse Oct-4 gene expression in embryonic stem cells and trophoblast stem cells. J Biol Chem 2004, 279:17063-17069.

10. Nishino K, Hattori N, Tanaka S, Shiota K: DNA methylation-mediated control of Sry gene expression in mouse gonadal development. J Biol Chem 2004, 279:22306-22313.

11. Hattori N, Imao Y, Nishino K, Ohgane J, Yagi S, Tanaka S, Shiota K: Epigenetic regulation of Nanog gene in embryonic stem and trophoblast stem cells. Genes Cells 2007, 12:387-396.

12. Sakamoto H, Kogo Y, Ohgane J, Hattori N, Yagi S, Tanaka S, Shiota K: Sequential changes in genome-wide DNA methylation status during adipocyte differentiation. Biochem Biophys Res Commun 2008, 366:360-366.

13. Maeda C, Sato S, Hattori N, Tanaka S, Yagi S, Shiota K: DNA hypomethylation circuit of the mouse oocyte-specific histone $\mathrm{H} 1$ foo gene in female germ cell lineage. Biol Reprod 2008, 78:816-821.

14. Khulan B, Thompson RF, Ye K, Fazzari MJ, Suzuki M, Stasiek E, Figueroa ME, Glass JL, Chen Q, Montagna C, Hatchwell E, Selzer RR, Richmond TA, Green RD, Melnick A, Greally JM: Comparative isoschizomer profiling of cytosine methylation: the HELP assay. Genome Res 2006, 16:1046-1055.

15. Rakyan VK, Down TA, Thorne NP, Flicek P, Kulesha E, Gräf S, Tomazou EM, Bäckdahl L, Johnson N, Herberth M, Howe KL, Jackson DK, Miretti MM, Fiegler H, Marioni JC, Birney E, Hubbard TJ, Carter NP, Tavaré S, Beck S: An integrated resource for genome-wide identification and analysis of human tissue-specific differentially methylated regions (tDMRs). Genome Res 2008, 18:1518-1529.

16. Hatada I, Namihira M, Morita S, Kimura M, Horii T, Nakashima K: Astrocytespecific genes are generally demethylated in neural precursor cells prior to astrocytic differentiation. PLoS One 2008, 3:e3189.

17. Mohn F, Weber M, Rebhan M, Roloff TC, Richter J, Stadler MB, Bibel M, Schübeler D: Lineage-specific polycomb targets and de novo DNA methylation define restriction and potential of neuronal progenitors. $\mathrm{Mol}$ Cell 2008, 30:755-766.

18. Meissner A, Mikkelsen TS, Gu H, Wernig M, Hanna J, Sivachenko A, Zhang X, Bernstein BE, Nusbaum C, Jaffe DB, Gnirke A, Jaenisch R, Lander ES: Genome-scale DNA methylation maps of pluripotent and differentiated cells. Nature 2008, 454:766-770.

19. Hirabayashi Y, Gotoh Y: Epigenetic control of neural precursor cell fate during development. Nat Rev Neurosci 2010, 11:377-388.

20. Sato S, Yagi S, Arai Y, Hirabayashi K, Hattori N, Iwatani M, Okita K, Ohgane J, Tanaka S, Wakayama T, Yamanaka S, Shiota K: Genome-wide DNA methylation profile of tissue-dependent and differentially methylated regions (T-DMRs) residing in mouse pluripotent stem cells. Genes Cells 2010, 15:607-618.

21. Johnson WE, Li W, Meyer CA, Gottardo R, Carroll JS, Brown M, Liu XS: Model-based analysis of tiling-arrays for ChIP-chip. Proc Natl Acad Sci USA 2006, 103:12457-12462.

22. Shiota K: DNA methylation profiles of $\mathrm{CpG}$ islands for cellular differentiation and development in mammals. Cytogenet Gennome Res 2004, 105:325-334.

23. Irizarry RA, Ladd-Acosta C, Wen B, Wu Z, Montano C, Onyango P, Cui H, Gabo K, Rongione M, Webster M, Ji H, Potash JB, Sabunciyan S, Feinberg AP: The human colon cancer methylome shows similar hypo- and hypermethylation at conserved tissue-specific CpG island shores. Nat Genet 2009, 41:178-186. 
24. Fazzari MJ, Greally JM: Epigenomics: beyond CpG islands. Nat Rev Genet 2004, 5:446-455.

25. Yagi S, Hirosawa M, Shiota K: DNA methylation profile: a composer-, conductor-, and player-orchestrated Mammalian genome consisting of genes and transposable genetic elements. J Reprod Dev 2012, 58:265-273.

26. Hutnick LK, Golshani P, Namihira M, Xue Z, Matynia A, Yang XW, Silva AJ, Schweizer FE, Fan G: DNA hypomethylation restricted to the murine forebrain induces cortical degeneration and impairs postnatal neuronal maturation. Hum Mol Genet 2009, 18:2875-2888.

27. Xu GL, Bestor TH, Bourc'his D, Hsieh CL, Tommerup N, Bugge M, Hulten M, Qu X, Russo JJ, Viegas-Péquignot E: Chromosome instability and immunodeficiency syndrome caused by mutations in a DNA methyltransferase gene. Nature 1999, 402:187-191.

28. Amir RE, Van den Veyver IB, Wan M, Tran CQ, Francke U, Zoghbi HY: Rett syndrome is caused by mutations in X-linked MECP2, encoding methyl-CpG-binding protein 2. Nat Genet 1999, 23:185-188.

29. O'Driscoll M, Cerosaletti KM, Girard PM, Dai Y, Stumm M, Kysela B, Hirsch B, Gennery A, Palmer SE, Seidel J, Gatti RA, Varon R, Oettinger MA, Neitzel H, Jeggo PA, Concannon P: DNA ligase IV mutations identified in patients exhibiting developmental delay and immunodeficiency. Mol Cell 2001 8:1175-1185.

30. Lu W, Quintero-Rivera F, Fan Y, Alkuraya FS, Donovan DJ, Xi Q, Turbe-Doan A, Li QG, Campbell CG, Shanske AL, Sherr EH, Ahmad A, Peters R, Rilliet B, Parvex P, Bassuk AG, Harris DJ, Ferguson H, Kelly C, Walsh CA, Gronostajski RM, Devriendt K, Higgins A, Ligon AH, Quade BJ, Morton CC, Gusella JF, Maas RL: NFIA haploinsufficiency is associated with a CNS malformation syndrome and urinary tract defects. PLoS Genet 2007, 3:e80.

31. Frank KM, Sharpless NE, Gao Y, Sekiguchi JM, Ferguson DO, Zhu C, Manis JP, Horner J, DePinho RA, Alt FW: DNA ligase IV deficiency in mice leads to defective neurogenesis and embryonic lethality via the p53 pathway. Mol Cell 2000, 5:993-1002.

32. Deuel TA, Liu JS, Corbo JC, Yoo SY, Rorke-Adams LB, Walsh CA: Genetic interactions between doublecortin and doublecortin-like kinase in neuronal migration and axon outgrowth. Neuron 2006, 49:41-53.

33. Demyanenko GP, Riday TT, Tran TS, Dalal J, Darnell EP, Brennaman LH, Sakurai T, Grumet M, Philpot BD, Maness PF: NrCAM deletion causes topographic mistargeting of thalamocortical axons to the visual cortex and disrupts visual acuity. J Neurosci 2011, 31:1545-1558.

34. Ohgane J, Wakayama T, Kogo Y, Senda S, Hattori N, Tanaka S, Yanagimachi R, Shiota K: DNA methylation variation in cloned mice. Genesis 2001, 30:45-50.

35. Arai Y, Ohgane J, Yagi S, Ito R, Iwasaki Y, Saito K, Akutsu K, Takatori S, Ishii R, Hayashi R, Izumi S, Sugino N, Kondo F, Horie M, Nakazawa H, Makino T, Shiota K: Epigenetic assessment of environmental chemicals detected in maternal peripheral and cord blood samples. J Reprod Dev 2011, 57:507-517.

36. Maekawa R, Yagi S, Ohgane J, Yamagata Y, Asada H, Tamura I, Sugino N, Shiota K: Disease-dependent differently methylated regions (D-DMRs) of DNA are enriched on the $\mathrm{X}$ chromosome in uterine leiomyoma. J Reprod Dev 2011, 57:604-612.

37. Lieb JD, Beck S, Bulyk ML, Farnham P, Hattori N, Henikoff S, Liu XS, Okumura K, Shiota K, Ushijima T, Greally JM: Applying whole-genome studies of epigenetic regulation to study human disease. Cytogenet Genome Res 2006, 114:1-15.

38. Jones PA, Baylin SB: The epigenomics of cancer. Cell 2007, 128:683-692.

39. Smedley D, Haider S, Ballester B, Holland R, London D, Thorisson G, Kasprzyk A: BioMart-biological queries made easy. BMC Genomics 2009, 10:22.

40. Giardine B, Riemer C, Hardison RC, Burhans R, Elnitski L, Shah P, Zhang Y, Blankenberg D, Albert I, Taylor J, Miller W, Kent WJ, Nekrutenko A: Galaxy: a platform for interactive large-scale genome analysis. Genome Res 2005, 15:1451-1455

41. Saeed Al, Sharov V, White J, Li J, Liang W, Bhagabati N, Braisted J, Klapa M, Currier T, Thiagarajan M, Sturn A, Snuffin M, Rezantsev A, Popov D, Ryltsov A, Kostukovich E, Borisovsky I, Liu Z, Vinsavich A, Trush V, Quackenbush J: TM4: a free, open-source system for microarray data management and analysis. Biotechniques 2003, 34:374-378.

42. Huang Da W, Sherman BT, Tan Q, Kir J, Liu D, Bryant D, Guo Y, Stephens R, Baseler MW, Lane HC, Lempicki RA: DAVID bioinformatics resources: expanded annotation database and novel algorithms to better extract biology from large gene lists. Nucleic Acids Res 2007 35(Web Server issue):W169-W175.

43. Sim FJ, McClain CR, Schanz SJ, Protack TL, Windrem MS, Goldman SA: CD140a identifies a population of highly myelinogenic, migrationcompetent and efficiently engrafting human oligodendrocyte progenitor cells. Nat Biotechnol 2011, 29:934-941.

doi:10.1186/1471-2164-14-82

Cite this article as: Hirabayashi et al:: DNA methylation profile dynamics of tissue-dependent and differentially methylated regions during mouse brain development. BMC Genomics 2013 14:82.

\section{Submit your next manuscript to BioMed Central and take full advantage of:}

- Convenient online submission

- Thorough peer review

- No space constraints or color figure charges

- Immediate publication on acceptance

- Inclusion in PubMed, CAS, Scopus and Google Scholar

- Research which is freely available for redistribution 